\title{
Cholera Rapid Diagnostic Tests for the Detection of Vibrio cholerae 01: An Updated Meta-Analysis
}

\author{
Basilua Andre Muzembo ${ }^{1, *}$, Kei Kitahara ${ }^{1,2}$, Ayumu Ohno ${ }^{1}$, Anusuya Debnath ${ }^{1}$, Keinosuke Okamoto ${ }^{1}$ \\ and Shin-Ichi Miyoshi ${ }^{1}$ \\ 1 Graduate School of Medicine, Dentistry and Pharmaceutical Sciences, Okayama University, \\ Okayama 700-8530, Japan; keikitahara@okayama-u.ac.jp (K.K.); py386nyz@okayama-u.ac.jp (A.O.); \\ anusuyadebnath@yahoo.co.in (A.D.); okamot-k@okayama-u.ac.jp (K.O.); miyos-s@okayama-u.ac.jp (S.-I.M.) \\ 2 Collaborative Research Center, Okayama University for Infectious Diseases in India, Kolkata 700010, India \\ * Correspondence: andersonbasilua@yahoo.fr or muzembo_andre@okayama.ac.jp
}

Citation: Muzembo, B.A.; Kitahara, K.; Ohno, A.; Debnath, A.; Okamoto, K.; Miyoshi, S.-I. Cholera Rapid Diagnostic Tests for the Detection of Vibrio cholerae O1: An Updated Meta-Analysis. Diagnostics 2021, 11, 2095. https://doi.org/10.3390/ diagnostics11112095

Academic Editor: Zeno Bisoffi

Received: 13 October 2021

Accepted: 11 November 2021

Published: 13 November 2021

Publisher's Note: MDPI stays neutral with regard to jurisdictional claims in published maps and institutional affiliations.

Copyright: (C) 2021 by the authors. Licensee MDPI, Basel, Switzerland. This article is an open access article distributed under the terms and conditions of the Creative Commons Attribution (CC BY) license (https:/ / creativecommons.org/licenses/by/ $4.0 /)$.
Abstract: The rapid diagnosis of cholera contributes to adequate outbreak management. This metaanalysis assesses the diagnostic accuracy of cholera rapid tests (RDTs) to detect Vibrio cholerae O1. Methods: Systematic review and meta-analysis. We searched four databases (Medline, EMBASE, Google Scholar, and Web of Science up to 8 September 2021) for studies that evaluated cholera RDTs for the detection of $V$. cholerae $\mathrm{O} 1$ compared with either stool culture or polymerase chain reaction (PCR). We assessed the studies' quality using the QUADAS-2 criteria. In addition, in this update, GRADE approach was used to rate the overall certainty of the evidence. We performed a bivariate random-effects meta-analysis to calculate the pooled sensitivity and specificity of cholera RDTs. Results: Overall, 20 studies were included in this meta-analysis. Studies were from Africa $(n=11)$, Asia $(n=7)$, and America (Haiti; $n=2)$. They evaluated eight RDTs (Crystal VC-O1, Crystal VC, Cholkit, Institut Pasteur cholera dipstick, SD Bioline, Artron, Cholera Smart O1, and Smart II Cholera O1). Using direct specimen testing, sensitivity and specificity of RDTs were $90 \%$ (95\% CI, 86 to 93 ) and $86 \%$ (95\% CI, 81 to 90), respectively. Cholera Sensitivity was higher in studies conducted in Africa [92\% (95\% CI, 89 to 94)] compared with Asia [82\% (95\% CI, 77 to 87)]. However, specificity [83\% (95\% CI, 71 to 91)] was lower in Africa compared with Asia [90\% (95\% CI, 84 to 94)]. GRADE quality of evidence was estimated as moderate. Conclusions: Against culture or PCR, current cholera RDTs have moderate sensitivity and specificity for detecting Vibrio cholerae O1.

Keywords: rapid test; cholera; Vibrio cholera O1; sensitivity; specificity; accuracy; update

\section{Introduction}

Despite centuries of effort, cholera (an acute diarrheal disease caused by Vibrio cholerae O1 or O139) remains a high-volume health issue, especially in Africa and the Indian subcontinents [1]. Channels of cholera transmission include the ingestion of food or drinking water contaminated with feces from an infected person or direct contact with infected feces. The risk of cholera outbreak is high in underprivileged communities with rudimentary access to safe water, adequate sanitation, and hygiene (WaSH) [2]. There were seven instances of cholera pandemics during the 19th and 20th centuries. Six of them emerged from the Ganges Delta in the Indian subcontinent and one from Indonesia (the ongoing seventh pandemic). From there, this human pathogen has spread rapidly across other continents such as Africa, the Americas, Europe, and other parts of Asia, killing millions of people $[1,3]$.

The disease remains a killer. About 95,000 deaths (range: 21,000-143,000) are reported every year worldwide [1]. Without any treatment, patients with severe cholera can die of dehydration and hypovolemic shock within hours after the onset of symptoms. Fortunately, timely treatment may limit cholera-related fatality, i.e., with appropriate case management, death would occur in $<1 \%$ of cholera patients [4]. Laboratory testing using microbiological 
culture and/or polymerase chain reaction (PCR) is required to confirm the etiology of cholera for strong public health responses. However, in some settings where cholera usually thrives, special laboratory equipment or trained laboratory technicians might not be readily available. Fortunately, cholera rapid diagnostic tests (RDTs) are used to screen patients with suspected cholera, and yield qualitative results within $30 \mathrm{~min}$ [5]. They prove especially useful in remote settings where microbiological culture and molecular testing are not easily accessible.

The Global Task Force on Cholera Control (GTFCC) recommends that cholera RDTs should have a sensitivity and a specificity of at least of $90 \%$ and $85 \%$, respectively [6]. In our previous systematic review and meta-analysis [7], we reported that the current cholera RDTs have suboptimal pooled sensitivity (91\%) and specificity (80\%).

Some of the limitations of our previous meta-analysis [7] are the non-assessment of the overall quality of evidence, lack of comparative data of RDTs performance across diverse geographical regions, and inclusion of RDTs that had positive or negative readings for $V$. cholera O139. In the interim, field studies including novel brands cholera RDT (Crystal VC-O1 and Smart II) have become available. Therefore, an updated synthesis of the accuracy of cholera RDTs is needed to assist clinicians and the global public health community to grasp a thorough picture of current cholera RDTs accuracy.

In this context, we aim to provide an updated summary of the accuracy of the current cholera RDTs and address some of the limitations of our previous meta-analysis.

\section{Methods}

We carried out a systematic review and meta-analysis of studies that evaluated the performance of the current RDTs in detecting $V$. cholerae O1 in stool samples compared to either stool culture or PCR. The Preferred Reporting Items for a Systematic Review and Meta-Analysis of Diagnostic Test Accuracy Studies (PRISMA-DTA) were followed [8]. This review is registered with the International Prospective Register of Systematic Reviews (PROSPERO CRD42021233124).

\subsection{Data Sources and Searches}

The search methods used were the same as those in our previous meta-analysis [7]. We searched MEDLINE through PubMed, EMBASE, Google Scholar, and Web of Science for studies published up to 8 September 2021, with no restrictions on language. We also checked and viewed the references of the included studies. (More details on the search strategy and study selection are available in our previously published meta-analysis [7].) In brief, eligible studies included cross-sectional studies with a sample size of at least 20 specimens. Studies were excluded if they used case-control designs, studies reporting only analytical sensitivity and specificity, and review articles.

\subsection{Outcomes}

In this updated meta-analysis, our primary outcome was the overall pooled sensitivity and specificity of RDTs to identify $V$. cholerae O1.

$V$. cholerae $\mathrm{O} 139$ test line readings were excluded.

\subsection{Data Extraction and Quality Assessment}

Two investigators (B.A.M. and K.K.) independently screened citations (titles and abstracts).

They also abstracted data and assessed the quality of the studies (risk of bias and applicability concerns) using the Quality Assessment of Diagnostic Accuracy Studies 2 (QUADAS-2) tool [9]. In addition, in this analysis, the Grading of Recommendations Assessment, Development and Evaluation (GRADE) approach was used to rate the quality of evidence for sensitivity and specificity [10].

Before beginning data extraction, we designed a data-extraction form. Extracted data included raw data on: the true positive; false positive; false negative; and true negative. 
This was used to construct $2 \times 2$ tables for applicable conditions. Any disagreements were resolved through consensus.

\subsection{Data Analysis}

Methods used here are as described in our previous meta-analysis [7]. We used the Stata software (version 16, StataCorp LP, College Station, TX, USA) to analyze data and generating plots. We constructed $2 \times 2$ tables of test results to calculate: the pooled sensitivity; specificity; positive likelihood ratio (LR; i.e., the ratio of individuals with the disease who test positive, to those who test positive but do not have the disease) and negative LR (i.e., the ratio of individuals with the disease who test negative, to those who test negative and do not have the disease); and the diagnostic odds ratio (DOR; i.e., the ratio of the odds of positivity when the disease is present to the odds of positivity in the non-diseased) with 95\% confidence intervals (CIs).

Meta-analysis was carried out using the generalized linear mixed model of the bivariate random effects model to account for the frequent heterogeneity expected from meta-analysis of diagnostic test accuracy studies [11].

Heterogeneity across studies was assessed by visual inspection of the shape of the hierarchical summary receiver-operating characteristic (HSROC) curves [12]. We did not use the $I^{2}$ statistic to assess heterogeneity. Other potential sources of heterogeneity were assessed during sensitivity analyses.

Data from studies that had evaluated more than one index test with the same specimens were all considered as data points and included in the analyses. In sensitivity analysis, studies were stratified into three geographic regions (i.e., Africa, Asia, and the Americas). We also performed a sensitivity analysis on Crystal VC because it had sufficient data points to be pooled separately. All results are presented with their 95\% CIs in parenthesis.

\section{Results}

\subsection{Literature Search}

Our updated search resulted in 7957 unique studies (Supplementary Figure S1), of which 3 met our inclusion criteria [13-15], yielding 8 new data points. These new data points were added to 37 data points from 17 studies from our previous meta-analysis [7]. Therefore, in this updated meta-analysis, we included 20 studies [13-32] with a total of 45 data points.

\subsection{Characteristics of Included Studies}

Table 1 describes the 20 included studies. The details of these 20 studies are shown in Table A1 in Appendix A. These studies evaluated eight RDT brands. Of these, Crystal VC was the most frequently studied RDT (15 studies). Other index tests included: Cholkit and Institut Pasteur cholera dipstick (three studies each); SD Bioline (two studies); Artron (one study); Smart (one study); Smart II Cholera O1(one study); and Crystal VC-O1 (one study). Crystal VC-O1 [13] and Smart II Cholera O1 [14] are the newest tests not included in our previous meta-analysis [7].

The studies were conducted in fourteen countries: four in Bangladesh [17,18,22,29]; three in India [14,15,26]; two in Haiti [23,31]; and one each in Cameroon [20]; Democratic Republic of the Congo [25]; Guinea Bissau [27]; Kenya [13]; Malawi [16]; Mozambique [28]; Nigeria [21]; South Sudan [32]; Tanzania [24]; Uganda [30]; and Zambia [19]. The three new studies included in this updated meta-analysis were conducted in Kenya [13] and India $[14,15]$.

Seven studies from Africa [16,19,21,24,25,27,32] and one from Haiti [23] stated clearly that RDTs were evaluated during outbreaks.

These studies provided 45 data points (with 19,280 stool specimens). 32 out of 45 used direct stool testing (with 15,877 stool specimens) and 13 used alkaline peptone water (APW) enrichment before testing. One study [14] that evaluated various RDTs with two different 
gold standard tests contributed to three additional data points using PCR as the gold standard (Table A2 in Appendix A).

Table 1. Characteristics of included studies.

\begin{tabular}{|c|c|c|}
\hline \multicolumn{2}{|c|}{ Study Characteristic } & \multirow{2}{*}{$\begin{array}{l}\text { Studies of Cholera Rapid Tests } \\
(\mathbf{N}=\mathbf{2 0}), \boldsymbol{n}(\mathbf{\%})\end{array}$} \\
\hline Study design & Cross-sectional & \\
\hline \multirow{3}{*}{ Industry funded } & Yes & $2(10.0)$ \\
\hline & No & $11(55.5)$ \\
\hline & Not reported & $7(35.5)$ \\
\hline Specimen type & Stool & $20(100)$ \\
\hline \multirow{3}{*}{ Testing type } & Direct stool testing & $11(55.0)$ \\
\hline & $\begin{array}{l}\text { Stool enrichment with } \\
\text { alkaline peptone water }\end{array}$ & $3(15.0)$ \\
\hline & Both & $6(30.0)$ \\
\hline \multirow{7}{*}{ Commercial brand } & Crystal VC & $15(75.0)$ \\
\hline & Crystal VC-O1 & $1(5.0)$ \\
\hline & Cholkit & $3(15.0)$ \\
\hline & Pasteur Cholera Dipstick & $3(15.0)$ \\
\hline & SD Bioline & $3(15.0)$ \\
\hline & Cholera Smart O1 & $1(5.0)$ \\
\hline & Smart II Cholera O1 & $1(5.0)$ \\
\hline Vibrio cholera strain detected & Vibrio cholera $\mathrm{O} 1$ & $20(100)$ \\
\hline \multirow{3}{*}{ Setting } & Africa & $11(55.5)$ \\
\hline & Asia & $7(35.0)$ \\
\hline & Americas & $2(10.0)$ \\
\hline
\end{tabular}

An overview of the methodological assessment of included studies is summarized in Table A3 in Appendix A. As in our previous meta-analysis [7], for the patient selection domain, high or unclear risk of bias was the main concern. We judged that the risk of bias was high or unclear in more than half of the studies $(11 / 20 ; 55 \%)$, mostly related to patients unclear inclusion or exclusion criteria. Most studies used conventional culture methods as a reference standard. However, PCR was also performed to confirm the etiologic agent in ten studies $[13,14,18-20,22,25,27,29,32]$. In these studies, PCR results were not always congruent with the results of conventional culture methods. Three studies $[20,27,32]$ used PCR alone as the reference standard and three other studies $[13,14,25]$ combined both PCR and culture as the reference standards.

\subsection{Meta-Analysis}

\subsubsection{Overall Performance}

Using the bivariate random-effects model (Table 2; Figure 1; and Supplementary Figure S2), direct specimen testing via cholera RDTs showed a pooled sensitivity of $90 \%$ ( $86 \%$ to $93 \%$ ) and pooled specificity of $86 \%(81 \%$ to $90 \%$ ) with moderate certainty of evidence (Table 3 ). The HSROC curve (Figure 2) shows greater heterogeneity in sensitivity (range: $66 \%$ to $100 \%$ ) and specificity (range: $47 \%$ to $100 \%$ ). About $47 \%$ of the data points $(15 / 32)$ had specificity below $85 \%$. Similarly, $47 \%$ of the data points $(15 / 32)$ also had a sensitivity below $90 \%$. The HSROC curve moderately approached the upper left-hand corner of the graph, indicating a moderate diagnostic performance. 
Table 2. Results of pooled sensitivity and specificity of cholera RDTs using direct fresh stool for $V$. cholerae O1 detection.

\begin{tabular}{|c|c|c|c|c|c|c|c|}
\hline Test & $\begin{array}{l}\text { Data Point } \\
\text { (n) }\end{array}$ & $\begin{array}{c}\text { Sample Size } \\
(n)\end{array}$ & $\begin{array}{c}\text { Pooled } \\
\text { Sensitivity } \\
(95 \% \text { CI }), \%\end{array}$ & $\begin{array}{c}\text { Pooled } \\
\text { Specificity } \\
(95 \% \text { CI), \% }\end{array}$ & $\begin{array}{c}\text { Positive LR } \\
\text { (95\% CI) }\end{array}$ & $\begin{array}{c}\text { Negative LR } \\
(95 \% \text { CI })\end{array}$ & $\begin{array}{c}\text { DOR } \\
(95 \% \mathrm{CI})\end{array}$ \\
\hline All * & 45 & 19,280 & 90 (86 to 93) & 91 (87 to 94$)$ & 10 (7 to 15$)$ & 0.11 (0.08 to 0.15$)$ & 89 (56 to 142$)$ \\
\hline $\begin{array}{c}\text { Direct } \\
\text { fresh stool }\end{array}$ & 32 & 15,877 & 90 (86 to 93) & 86 (81 to 90$)$ & 7 (5 to 9$)$ & 0.12 (0.09 to 0.16$)$ & 56 (37 to 86$)$ \\
\hline
\end{tabular}

Definition of abbreviations: RDT = rapid diagnostic test; $\mathrm{CI}$ = confidence interval; $\mathrm{LR}$ = likelihood ratio; DOR = diagnostic odds ratio; $\mathrm{APW}=$ alkaline peptone water. * All (we included all data points: direct stool testing and after APW enrichment). Included tests were: Crystal VC; Cholkit; Institut Pasteur cholera dipstick; SD Bioline; Smart; SMART-II; Crystal VC-O1; and Artron.

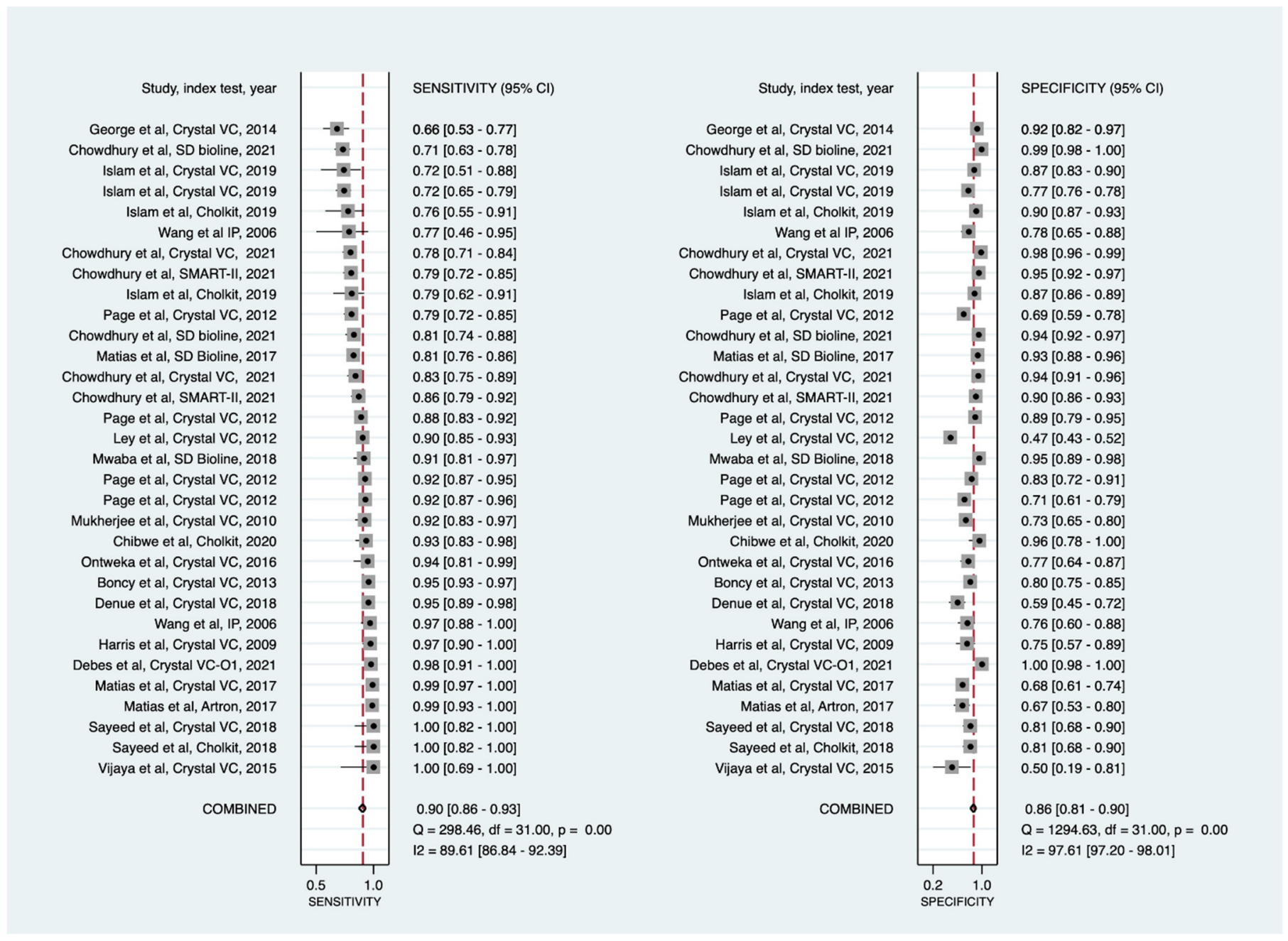

Figure 1. Forest plots of the sensitivities and specificities of cholera rapid diagnostic tests (direct stool testing) for the detection of Vibrio cholerae O1. CI = confidence interval; IP= Institut Pasteur. Data points are sorted by sensitivity performance. 
Table 3. GRADE certainty of evidence for cholera RDTs: should current cholera RDTs be used in patients suspected of cholera for surveillance or earlier outbreak detection?

\begin{tabular}{|c|c|c|c|c|c|c|c|c|}
\hline \multirow[t]{2}{*}{ Outcome } & \multirow{2}{*}{$\begin{array}{c}\text { Number of Studies } \\
\text { (Number of } \\
\text { Specimens) }\end{array}$} & \multirow[t]{2}{*}{ Study Design } & \multicolumn{5}{|c|}{ Factors that May Lower Certainty of Evidence } & \multirow{2}{*}{$\begin{array}{c}\text { Test Accuracy } \\
\text { Certainty of } \\
\text { Evidence }\end{array}$} \\
\hline & & & Risk of bias & Indirectness & Inconsistency & Imprecision & $\begin{array}{l}\text { Publication } \\
\text { bias }\end{array}$ & \\
\hline $\begin{array}{l}\text { True positives (patients } \\
\text { correctly identified as } \\
\text { having with cholera) }\end{array}$ & $20(15,877)$ & Cross-sectional & Serious ${ }^{a}$ & Not serious & Very serious ${ }^{b}$ & Serious ${ }^{c}$ & Likely ${ }^{d}$ & $\begin{array}{c}\text { Moderate } \\
\oplus \oplus \oplus\end{array}$ \\
\hline $\begin{array}{l}\text { False negative (patients } \\
\text { incorrectly identified as not } \\
\text { having cholera) }\end{array}$ & $20(15,877)$ & Cross-sectional & Serious ${ }^{a}$ & Not serious & Very serious ${ }^{b}$ & Serious ${ }^{c}$ & Likely $^{\mathrm{d}}$ & $\begin{array}{c}\text { Moderate } \\
\oplus \oplus \oplus \bigcirc\end{array}$ \\
\hline $\begin{array}{c}\text { True negatives (patients } \\
\text { correctly identified as not } \\
\text { having cholera) }\end{array}$ & $20(15,877)$ & Cross-sectional & Serious $^{a}$ & Not serious & Very serious ${ }^{b}$ & Serious ${ }^{c}$ & Likely ${ }^{d}$ & $\begin{array}{c}\text { Moderate } \\
\oplus \oplus \oplus \bigcirc\end{array}$ \\
\hline $\begin{array}{l}\text { False positives (patients } \\
\text { incorrectly identified as } \\
\text { having cholera) }\end{array}$ & $20(15,877)$ & Cross-sectional & Serious $^{a}$ & Not serious & Very serious ${ }^{b}$ & Serious ${ }^{c}$ & Likely $^{\mathrm{d}}$ & $\begin{array}{c}\text { Moderate } \\
\oplus \oplus \oplus \bigcirc\end{array}$ \\
\hline
\end{tabular}

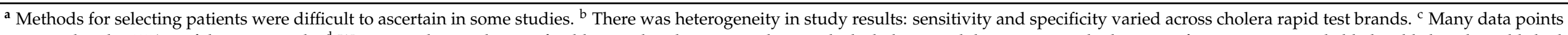

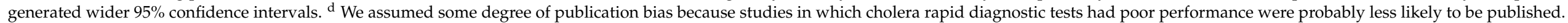
However, we did not downgrade the quality of evidence as a formal assessment of publication bias was not performed. 


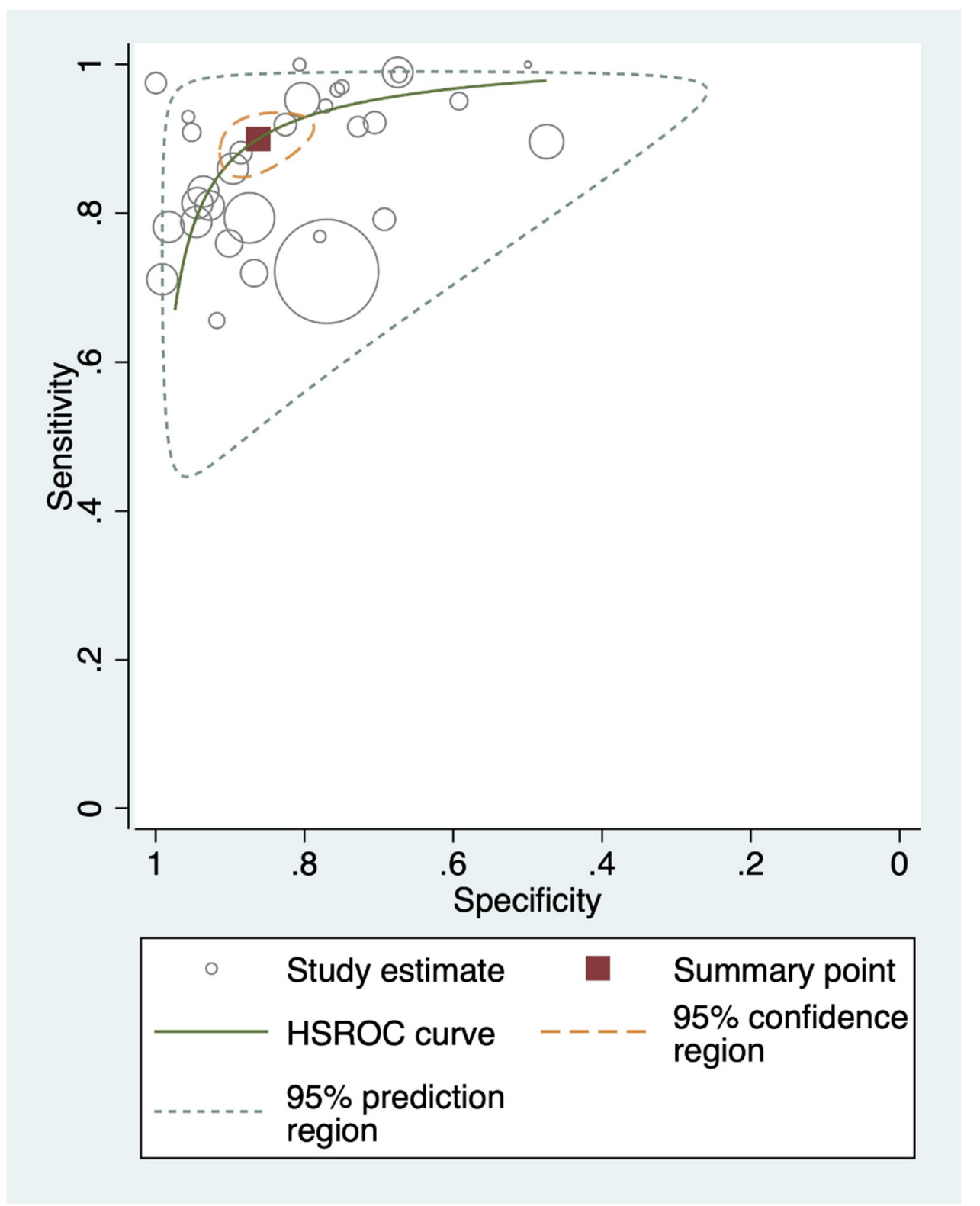

Figure 2. Hierarchical summary receiver-operating characteristic curves of the sensitivity and specificity of cholera rapid diagnostic tests (direct testing of fresh stools). Each circle represents the sensitivity and specificity of each included data point $(n=32)$. The summary point refers to pooled sensitivity and specificity. Sensitivity $=90 \%(95 \%$ CI, 86 to 93$)$ and specificity $=86 \%(95 \%$ CI, 81 to 90). GTFCC recommends that cholera RDTs should be at least $90 \%$ sensitive and $85 \%$ specific. $\mathrm{CI}=$ confidence interval; HSROC = hierarchical summary receiver-operating characteristics; GTFCC = Global Task Force on Cholera Control.

\subsubsection{Sensitivity Analyses}

The pooled sensitivity in the studies using direct specimens testing slightly decreased [88\% $(84 \%$ to $92 \%)$ ] when we included three additional data points from the new study performed in India (where PCR was used as the gold standard) [14]. However, the pooled specificity slightly increased to $87 \%$ (83\% to 91\%) (Supplementary Figure S3A,B). 


\section{Crystal VC RDTs}

When crystal VC was used for direct specimens testing (19 data points with 11,042 specimens), the pooled sensitivity and specificity were $91 \%(86 \%$ to $94 \%)$ and $82 \%$ ( $73 \%$ to $89 \%$ ), respectively (Figure 3 and Supplementary Figure S4). Seven data points (37\%; $7 / 19$ ) had sensitivity estimates below the minimal performance of $90 \%$, and only six data points $(32 \% ; 6 / 19)$ reached the minimal performance specificity of $85 \%$.

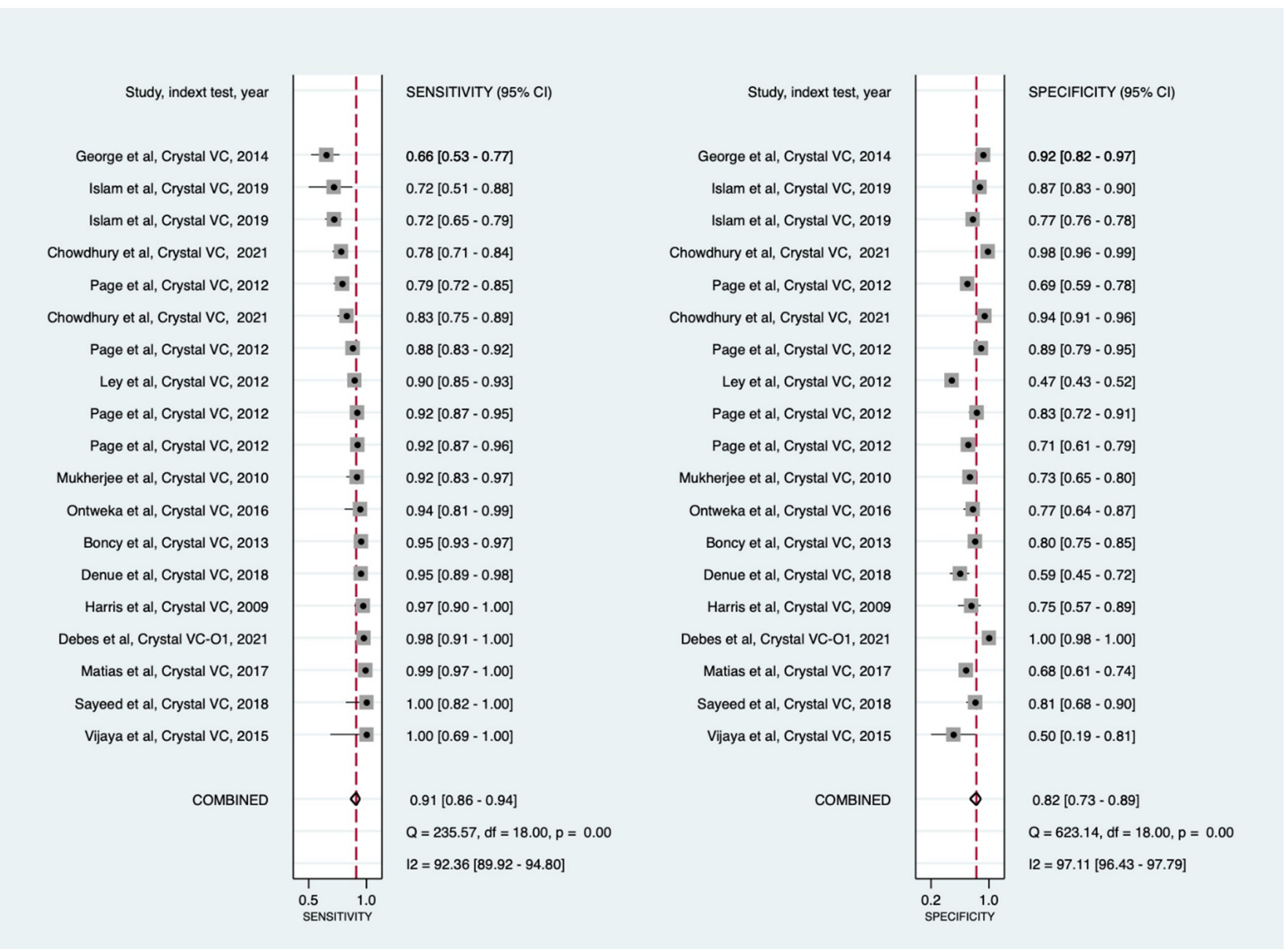

Figure 3. Forest plots of the sensitivities and specificities of Crystal VC cholera rapid diagnostic test for the detection of Vibrio cholerae $\mathrm{O} 1$ (direct stool testing).

It is important to note that one new study using Crystal VC-O1 reported higher estimates of sensitivity (98\%) and specificity (100\%) [13].

\section{Cholera RDTs by Geographic Regions}

We assessed whether cholera RDTs performance varied across settings. We noted that pooled sensitivity and specificity were highly variable when analyses were stratified by continents for direct specimens testing (Table 4; Figures 4-6). Cholera Sensitivity was higher in studies conducted in Africa [92\% (89\% to 94\%)] compared to those conducted in Asia [82\% (77\% to $87 \%)$ ]. However, specificity [ $83 \%(71 \%$ to $91 \%)]$ was lower in Africa compared to Asia [90\% (84\% to $94 \%)$ ]. Studies conducted in the Americas (Haiti) provided a pooled sensitivity of $96 \%$ ( $88 \%$ to $99 \%)$ and a pooled specificity of $79 \%(65 \%$ to $89 \%)$. 
Table 4. Pooled sensitivity and specificity of cholera RDTs stratified by geographical regions.

\begin{tabular}{|c|c|c|c|c|c|c|c|}
\hline Subgroup & $\begin{array}{l}\text { Data Point } \\
\quad(n)\end{array}$ & $\begin{array}{l}\text { Sample } \\
\text { Size }(n)\end{array}$ & $\begin{array}{c}\text { Pooled } \\
\text { Sensitivity } \\
(95 \% \text { CI), \% }\end{array}$ & $\begin{array}{c}\text { Pooled } \\
\text { Specificity } \\
(95 \% \text { CI }), \%\end{array}$ & $\begin{array}{l}\text { Positive LR } \\
\text { (95\% CI) }\end{array}$ & $\begin{array}{c}\text { Negative LR } \\
(95 \% \text { CI) }\end{array}$ & $\begin{array}{c}\text { DOR } \\
(95 \% \mathrm{CI})\end{array}$ \\
\hline Africa * & 13 & 2644 & 92 (89 to 94$)$ & 83 (71 to 91$)$ & $6(3$ to 10$)$ & 0.09 (0.06 to 0.14$)$ & 59 (24 to 145$)$ \\
\hline $\begin{array}{c}\text { Asia } \\
\text { (Bangladesh } \\
\text { and India) }\end{array}$ & 15 & 11,527 & 82 (77 to 87$)$ & $90(84$ to 94$)$ & 8 (5 to 13$)$ & $0.20(0.15$ to 0.26$)$ & 42 (26 to 69$)$ \\
\hline $\begin{array}{l}\text { Americas } \\
\text { (Haiti) } * * *\end{array}$ & 4 & 1706 & 96 (88 to 99) & 79 (65 to 89$)$ & 5 (3 to 6$)$ & $0.05(0.02$ to 0.13$)$ & 99 (52 to 187 ) \\
\hline
\end{tabular}

Definition of abbreviations: $\mathrm{RDT}=$ rapid diagnostic test; $\mathrm{CI}=$ confidence interval; $\mathrm{LR}=$ likelihood ratio; $\mathrm{DOR}=$ diagnostic odds ratio. * Included tests were: Crystal VC; Cholkit; Institut Pasteur cholera dipstick; SD Bioline; Smart; and Crystal VC-O1. ${ }^{* *}$ Included tests were: Crystal VC; Cholkit; SD Bioline; Smart; and SMART-II. ${ }^{* * *}$ Included tests were: Crystal VC; SD Bioline; and Artron.

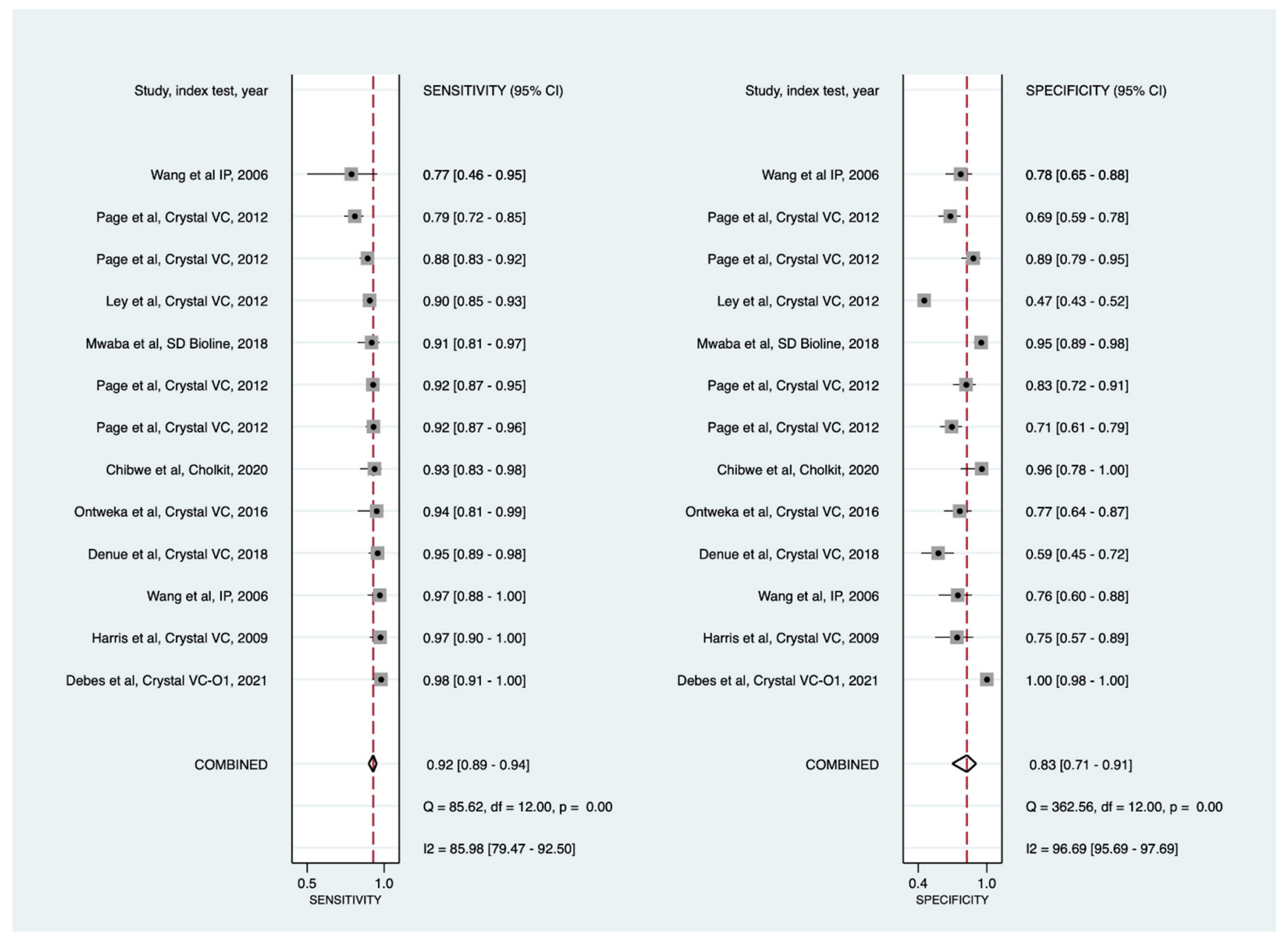

Figure 4. Forest plots of the sensitivities and specificities of cholera rapid diagnostic tests (direct stool testing) with their $95 \%$ confidence intervals. This subanalysis was restricted to studies conducted in Africa. $\mathrm{CI}=$ confidence interval; IP = Institut Pasteur. 


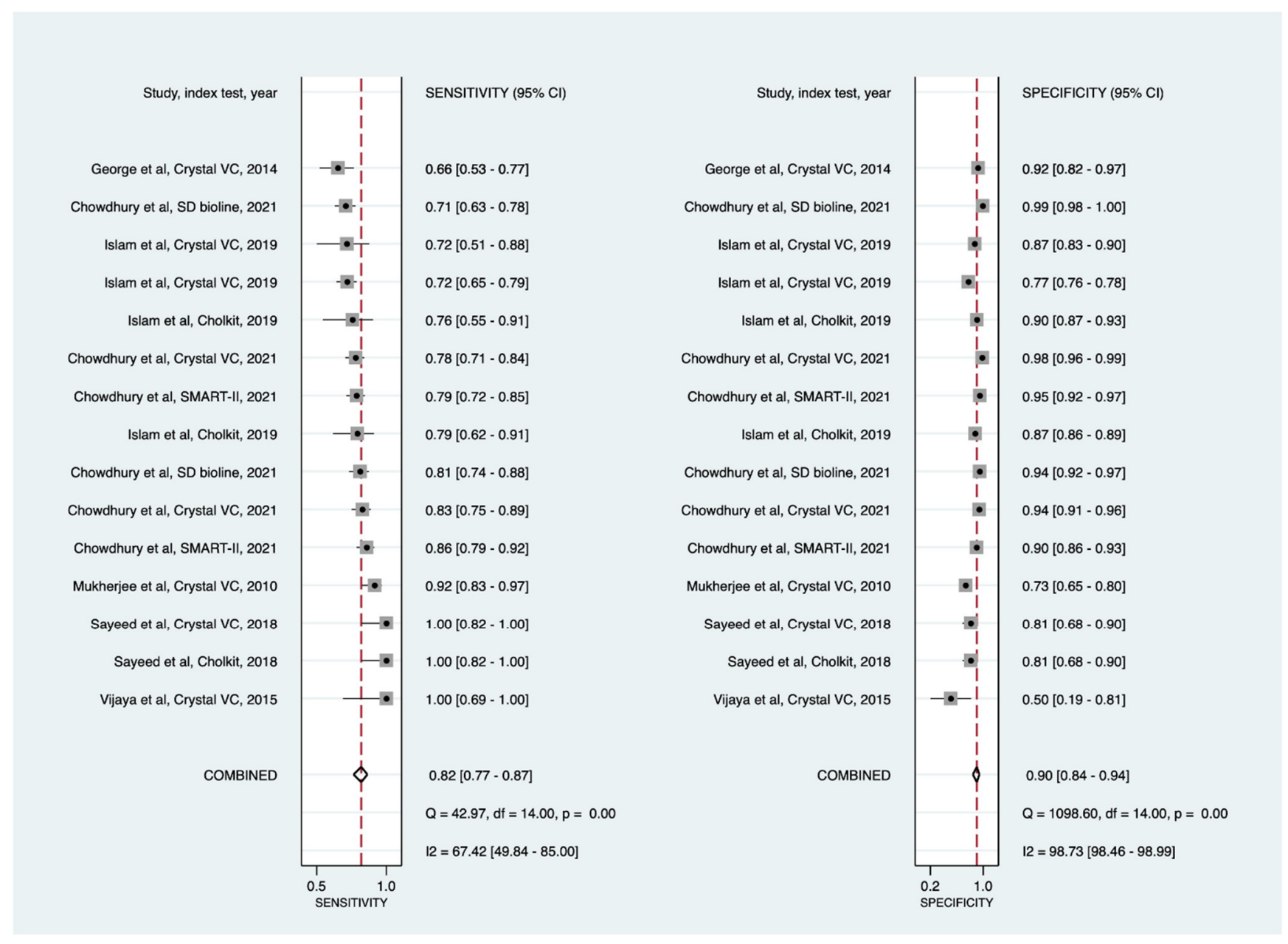

Figure 5. Forest plots of the sensitivities and specificities of cholera rapid diagnostic tests (direct stool testing) with their $95 \%$ confidence intervals. This sub-analysis was restricted to studies conducted in Asia (Bangladesh and India). $\mathrm{CI}=$ confidence interval.

Outbreak-related stool specimens from Africa [16,19,21,24,25,27,32] and Haiti [23] showed sensitivity $\geq 90 \%$.

\section{Direct and APW Enrichment Testing}

Pooled sensitivity was $90 \%$ ( $86 \%$ to $93 \%$ ) and pooled specificity was $91 \%$ ( $87 \%$ to $94 \%$ ) when all the 45 data points (with 19,280 specimens) from both direct stool testing and after APW enrichment were combined (Table 2 and Supplementary Figure S5). 


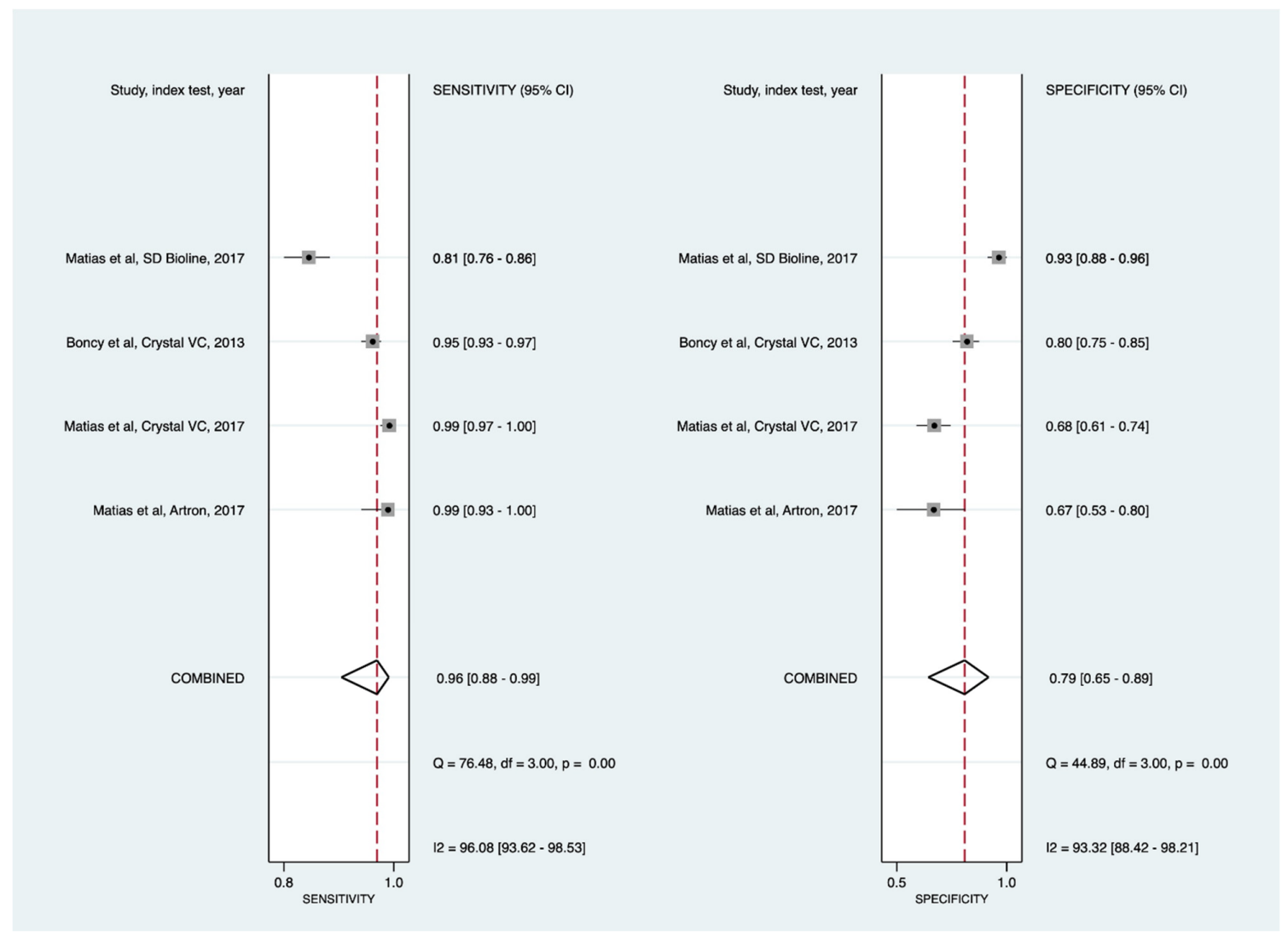

Figure 6. Forest plots of the sensitivities and specificities of cholera rapid diagnostic tests (direct stool testing) with their $95 \%$ confidence intervals. This subanalysis was restricted to studies conducted in the Americas (Haiti). CI = confidence interval.

\section{Discussion}

This updated meta-analysis assessed accuracy of RDTs used for cholera screening in suspected patients. We assessed the performance of current RDTs using 32 data points (for direct specimen testing) including eight new data points ( $25 \%$ of the included data points) identified since our previous meta-analysis [7]. Unlike our previous meta-analysis, in this meta-analysis, the outcome was restricted to the detection of V. cholerae $\mathrm{O} 1$ and the performance of cholera RDTs across continents was highlighted. The findings of current meta-analysis are consistent with those of our previous meta-analysis [7]: via direct specimen testing, cholera RDTs showed a moderate pooled sensitivity $(90 \%$; versus $91 \%$ in our previous meta-analysis) and specificity ( $86 \%$; versus $80 \%$ in our previous metaanalysis). Study results were heterogenous with substantial uncertainty in performance; that is, the sensitivity (ranging from 66\% to 100\%) and specificity (ranging from $47 \%$ to $100 \%$ ) of current cholera RDTs vary considerably, suggesting that improvements in the accuracy of cholera RDTs are urgently needed. We deduced some factors that may account for this heterogeneity with potential public health implications. For instance, location of RDTs usage was a source of heterogeneity in RDTs performance. RDTs showed a relatively higher pooled sensitivity but lower specificity in studies conducted in Africa and in the Americas than in Asia.

Although other explanations may be possible, we speculate that this relatively improved pooled sensitivity seen in Africa and the Americas could have been due to the fact that most of the stool specimens from Africa and the Americas were outbreak-related. However, the specimens from Asia were collected during surveillance. Since cholera RDTs were assessed during outbreaks in Africa, it was surmised that a significant number of samples were tested within a shorter period of time, which could have influenced RDT sensitivity. Furthermore, as $V$. cholerae strains may vary substantially in different geographical regions throughout the world, so too may the sensitivity of existing cholera RDTs. 
These data suggest that during surveillance or at the beginning of outbreaks, a negative cholera RDT result does not rule out cholera in a person with clinical symptoms of cholera. Thus, in such situations, even negative cholera RDT results should be confirmed using microbiological culture and/or PCR.

We noted that when the analyses were restricted to studies carried out in Africa, the specificity was $83 \%$. The pooled specificity of $83 \%$ meant that for every 100 people tested who were not infected by $V$. cholerae $\mathrm{O} 1,17$ had positive results. This is important in the context of concerns related to diverting the resources for unnecessary further testing (e.g., stool culture), which may increase the effort spent on testing. However, studies conducted in Asia showed slightly higher specificity $(90 \%)$, which meant that $10 \%$ would have had a positive result without any infection. This suggests that every positive result obtained with cholera RDT does not automatically rule in cholera due to the potential for false positive results. During outbreaks, an increase of true positives is likely to be seen at the cost of increasing false positives. Cross-reactivity between $V$. cholerae $\mathrm{O} 1$ antibodies and "undefined entities" in stool specimens have been hypothesized to account for the false positives [26]. Issues occurring due to this suboptimal accuracy of current RDTs include the reluctance of health providers to report a cholera outbreak using RDT alone, or, conversely, to trigger an outbreak response using RDT alone. This, in turn, can delay a mitigatory response to a cholera outbreak [33].

For all these reasons, clinicians should be aware of the limitations of these RDTs (i.e., the unreliability of positive as well as negative results). Positive RDTs should always be validated by PCR, microbiological analyses, or the combination of both.

Despite their suboptimal accuracy, cholera RDTs remain a useful tool during outbreaks as they are suited to be used outside a laboratory setting, are easy to operate with a quick turnaround time, and are good for community health workers because they can help to detect cholera transmission in communities. In addition, the high accuracy of some newly developed cholera RDT brands such as Cholkit [16-18] and Crystal VC-O1 [13] suggests great potential and should be confirmed in more field studies. However, it should be noted that studies that evaluated Cholkit or Crystal VC-O1 were either industry-sponsored or received RDTs kits from the developer/manufacturer.

We could not perform meta-analysis on all RDTs on an individual basis due to a lack of data. Crystal-VC, the most tested RDT in the field, was assessed separately as new data points were available (Figure 3).

In this updated meta-analysis, Crystal VC pooled sensitivity was the same as in our previous estimate ( $91 \%$ ), but pooled specificity increased to $82 \%$ (versus $75 \%$ in our previous estimates [7]). This slight increase in specificity is due, in part, to the high specificity found with the newly developed Crystal VC-O1 [13], and Crystal VC that was used with enriched culture methods by Chowdhury and colleagues [14]. This improved pooled specificity was still below the $85 \%$ specificity recommended by GTFCC [6]. Therefore, these data provide a unique opportunity to advocate for the continuation of research to develop and validate newer cholera RDTs.

It is crucial to remind health practitioners that the selection of a gold standard may impact the sensitivity and specificity of an index test. Simply, an imperfect gold standard bias has raised concerns about underestimating the sensitivity and specificity of an index test [34]. Microbiological culture can be affected by viable but non-culturable $V$. cholerae, antibiotics consumption, and lytic bacteriophages [35,36]. For instance, one study reported the presence of $V$. cholerae $\mathrm{O} 1$ lytic phages (denoting cholera etiology) in half of the dipstick tests that were positive for $V$. cholerae $\mathrm{O} 1$, but those stool specimens were negative using culture [36]. Some misclassification with PCR may occur: PCR can misclassify a patient without cholera as having the disease if the $V$. cholerae cells are dead or the quantity of viable cells is low in a stool sample, especially in the context of the prior administration of antibiotics [26]. Therefore, it is theoretically possible that in studies where PCR was used as the gold standard, the sensitivity of cholera RDTs would have been underestimated. In this meta-analysis, of all the studies reviewed concerning direct testing, three studies used PCR 
as the gold standard: sensitivity was reportedly high in two studies, between $94 \%$ [32] and 97\% [27]. However, sensitivity was low when cholera RDTs were compared with PCR in one study, between $52 \%$ and $58 \%$ [14], which affected the overall RDTs pooled sensitivity [i.e., slightly decreased to $88 \%$ (Supplementary Figure S3A,B)]. Poor laboratory capacity can make the matter worse. For example, during an outbreak in Nigeria, a local laboratory failed to confirm a positive RDT by microbiological culture (provided negative result by stool culture), but a positive RDT was subsequently confirmed in a regional reference laboratory ten days later [33].

A notable input of this current review is the use of the GRADE approach (Table 3). We found that certainty of evidence was moderate, driven in large part by the potential for bias associated with difficulties to ascertain methods for selecting or excluding patients in some studies, inconsistency (considerable variability in sensitivity and specificity across studies), and imprecision (most of the studies reported wider 95\% CI).

One of the limitations of this study stems from our inability to account for disease severity effect in this meta-analysis because of a lack of data. It is, therefore, imperative for future field studies to evaluate the performance of cholera RDTs considering the disease severity. As a case in point, one study reported that cholera RDTs performance were similar across disease spectrum [14].

It is important to note that existing commercially available RDTs for infectious diseases vary widely in sensitivity and specificity performance, depending on the RDT brand and ailment. D. Bouzid and colleagues have recently summarized their reliability and validity in clinical settings [37].

We conclude that current cholera RDTs have moderate accuracy. Cholera RDTs will continue to be helpful in outbreak detection or surveillance purposes, ultimately assisting in cholera control efforts. It is therefore crucial for primary health practitioners to be aware of their availability, their performance, and limitations. These data call for research to develop alternative, simple cholera RDTs with both high sensitivity and specificity. In addition, more field evaluation on the performance of Cholkit and Crystal VC-O1 is needed.

Supplementary Materials: The following are available online at https://www.mdpi.com/article/10 .3390/diagnostics11112095/s1, Figure S1: Flow chart of included studies, Figure S2: Forest plots of the sensitivities and specificities of cholera rapid diagnostic tests (direct stool testing) for the detection of Vibrio cholerae O1, Figure S3: (A) Hierarchical summary receiver-operating characteristic curves of the sensitivity and specificity of cholera rapid diagnostic tests (direct stool testing), (B) Forest plots of the sensitivities and specificities of cholera rapid diagnostic tests, Figure S4: Forest plots of the sensitivities and specificities of Crystal VC cholera rapid diagnostic test for the detection of Vibrio cholerae O1 (direct stool testing), Figure S5: Hierarchical summary receiver-operating characteristic curves of the sensitivity and specificity of cholera rapid diagnostic tests (direct testing stools and after alkaline peptone water enrichment).

Author Contributions: B.A.M. and S.-I.M.: study conception and its design; B.A.M. and K.K.: data collection, analysis and interpretation; B.A.M.: wrote the first draft of the manuscript; K.K. and A.O.: commented on an early version of the manuscript; K.K., A.O., A.D., K.O. and S.-I.M.: revised the manuscript for important academic content; S.-I.M.: supervised this work. All authors have read and agreed to the published version of the manuscript.

Funding: This study was supported by the Japan Initiative for Global Research Network on Infectious Diseases (J-GRID) from the Ministry of Education, Culture, Sports, Science \& Technology in Japan (MEXT), and the Japan Agency for Medical Research and Development (AMED; Grant No. JP20wm0125004). The funders had no role in its study design, data collection and analysis, decision to publish, or preparation of the manuscript.

Acknowledgments: We would like to express our gratitude to the reviewers for their input. We would also like to thank Mansongi Biyela Carine for her assistance in searching for articles manually.

Conflicts of Interest: The authors declare no conflict of interest. The funders had no role in the design of the study; in the collection, analyses, or interpretation of data; in the writing of the manuscript, or in the decision to publish the results. 


\section{Appendix A}

Table A1. Summary of reviewed studies.

\begin{tabular}{|c|c|c|c|c|c|c|c|c|c|c|c|}
\hline Study & Location & Study Period & Study Design & $\begin{array}{l}\text { Participants' } \\
\text { Age (Year; Mean } \\
\text { or Median)/ } \\
\text { Descriptor }\end{array}$ & User & $\begin{array}{l}\text { Industry } \\
\text { Funded (Yes } \\
\text { or No) }\end{array}$ & Population & Specimen Type & Index Test & $\begin{array}{l}\text { Reference } \\
\text { Standard }\end{array}$ & $\begin{array}{c}\text { Sample } \\
\text { Size }\end{array}$ \\
\hline $\begin{array}{l}\text { Debes et al., } \\
2021 \text { [13] }\end{array}$ & Kenya & 2018 to 2019 & $\begin{array}{c}\text { Cross- } \\
\text { sectional }\end{array}$ & $\begin{array}{l}\text { All age groups } \\
(\text { mean }=25)\end{array}$ & Lab technician & $\begin{array}{l}\text { No, but received } \\
\text { RDT kit from the } \\
\text { manufacturer }\end{array}$ & $\begin{array}{l}\text { Hospital samples: Individuals } \\
\text { presenting to a health facility with } \\
\text { acute watery diarrhea. }\end{array}$ & Stool & Crystal VC-O1 & $\begin{array}{l}\text { Culture and } \\
\text { PCR }\end{array}$ & 230 \\
\hline $\begin{array}{l}\text { Chowdhury } \\
\text { et al., } 2021 \text { [14] }\end{array}$ & India & 2016 and 2017 & $\begin{array}{l}\text { Cross- } \\
\text { sectional }\end{array}$ & All age groups & Lab technician & No & $\begin{array}{l}\text { Hospital samples: Individuals } \\
\text { hospitalized for diarrhea and } \\
\text { children treated for diarrhea as } \\
\text { outpatients at designated hospitals. }\end{array}$ & Stool & $\begin{array}{l}\text { SD bioline } \\
\text { cholera, } \\
\text { SMART-II } \\
\text { Cholera O1 and } \\
\text { Crystal VC }\end{array}$ & $\begin{array}{l}\text { Culture and } \\
\text { PCR }\end{array}$ & 506 \\
\hline \multirow{6}{*}{$\begin{array}{l}\text { Islam et al., } \\
2019 \text { [17] }\end{array}$} & \multirow{6}{*}{ Bangladesh } & \multirow{6}{*}{$\begin{array}{l}\text { Ongoing } \\
\text { surveillance } \\
\text { since } 2016\end{array}$} & \multirow{6}{*}{$\begin{array}{c}\text { Cross- } \\
\text { sectional }\end{array}$} & \multirow{6}{*}{ Mean $=19$} & \multirow{6}{*}{ Lab technician } & \multirow{6}{*}{ Yes } & \multirow{6}{*}{$\begin{array}{l}\text { Hospital samples: Individuals } \\
\text { presenting to hospitals with acute } \\
\text { watery diarrhea. }\end{array}$} & \multirow{4}{*}{ Stool } & \multirow{4}{*}{ Crystal VC } & \multirow{4}{*}{ Culture } & 381 \\
\hline & & & & & & & & & & & 5865 \\
\hline & & & & & & & & & & & 614 \\
\hline & & & & & & & & & & & 381 \\
\hline & & & & & & & & \multirow[t]{2}{*}{ Stool } & \multirow[t]{2}{*}{ Cholkit } & \multirow[t]{2}{*}{ Culture } & 1355 \\
\hline & & & & & & & & & & & 424 \\
\hline Denue, 2018 [21] & Nigeria & 2017 & $\begin{array}{l}\text { Cross- } \\
\text { sectional }\end{array}$ & Mean $=20$ & Lab technician & No & $\begin{array}{l}\text { Hospital samples: Individuals } \\
\text { presenting to a cholera treatment } \\
\text { unit with diarrhea. }\end{array}$ & Stool & Crystal VC & Culture & 156 \\
\hline \multirow{2}{*}{$\begin{array}{l}\text { Sayeed et al., } \\
2018 \text { [18] }\end{array}$} & \multirow{2}{*}{ Bangladesh } & \multirow{2}{*}{ Not reported } & \multirow{2}{*}{$\begin{array}{c}\text { Cross- } \\
\text { sectional }\end{array}$} & \multirow{2}{*}{ Median $=26$} & \multirow{2}{*}{ Lab technician } & \multirow{2}{*}{ Yes } & \multirow{2}{*}{$\begin{array}{l}\text { Hospital samples: Patients } \\
\text { presenting to the icddr, b hospital } \\
\text { with acute watery diarrhea. }\end{array}$} & Stool & Cholkit & Culture & 76 \\
\hline & & & & & & & & Stool & Crystal VC & & 76 \\
\hline \multirow{3}{*}{$\begin{array}{l}\text { Matias et al., } \\
2017 \text { [31] }\end{array}$} & \multirow{3}{*}{ Haiti } & \multirow{3}{*}{ 2014-2015 } & \multirow{3}{*}{$\begin{array}{c}\text { Cross- } \\
\text { sectional }\end{array}$} & \multirow{3}{*}{ Not reported } & \multirow{3}{*}{ Lab technician } & \multirow{3}{*}{ No } & \multirow{3}{*}{$\begin{array}{l}\text { Hospital samples: Patients } \\
\text { presenting to a cholera treatment } \\
\text { center with acute watery diarrhea. }\end{array}$} & \multirow{3}{*}{ Stool } & Crystal VC & Culture & 511 \\
\hline & & & & & & & & & Artron & Culture & 129 \\
\hline & & & & & & & & & SD Bioline & Culture & 451 \\
\hline $\begin{array}{l}\text { Bwire et al., } \\
2017 \text { [30] }\end{array}$ & Uganda & 2015 & $\begin{array}{l}\text { Cross- } \\
\text { sectional }\end{array}$ & All age groups & Lab technician & No & $\begin{array}{l}\text { Hospital samples: Suspected } \\
\text { cholera patients presenting to } \\
\text { hospitals. }\end{array}$ & $\begin{array}{l}\text { Stool/rectal } \\
\text { swabs }\end{array}$ & Crystal VC & Culture & 102 \\
\hline
\end{tabular}


Table A1. Cont.

\begin{tabular}{|c|c|c|c|c|c|c|c|c|c|c|c|}
\hline Study & Location & Study Period & Study Design & $\begin{array}{l}\text { Participants' } \\
\text { Age (Year; Mean } \\
\text { or Median)/ } \\
\text { Descriptor }\end{array}$ & User & $\begin{array}{l}\text { Industry } \\
\text { Funded (Yes } \\
\text { or No) }\end{array}$ & Population & Specimen Type & Index Test & $\begin{array}{l}\text { Reference } \\
\text { Standard }\end{array}$ & $\underset{\text { Size }}{\text { Sample }}$ \\
\hline $\begin{array}{l}\text { Ontweka et al., } \\
2016[32]\end{array}$ & South Sudan & 2015 & $\begin{array}{l}\text { Cross- } \\
\text { sectional }\end{array}$ & Median $=26$ & Lab technician & No & $\begin{array}{l}\text { Hospital samples: Patients } \\
\text { presenting to cholera treatment } \\
\text { centers with acute watery diarrhea. }\end{array}$ & Stool & Crystal VC & PCR & 101 \\
\hline $\begin{array}{l}\text { Debes et al., } \\
2016[20]\end{array}$ & Cameroon & 2013-2014 & $\begin{array}{c}\text { Cross- } \\
\text { sectional }\end{array}$ & All age groups & Lab technician & No & $\begin{array}{l}\text { Hospital samples: Patients with } \\
\text { acute non-blood watery diarrhea. }\end{array}$ & Stool & Crystal VC & PCR & 673 \\
\hline $\begin{array}{l}\text { Vijaya et al., } \\
2015[15]\end{array}$ & India & Not reported & $\begin{array}{l}\text { Cross- } \\
\text { sectional }\end{array}$ & Not reported & Researcher & Not reported & $\begin{array}{l}\text { Hospital samples: Patients } \\
\text { presenting to a tertiary care } \\
\text { hospital with acute watery diarrhea }\end{array}$ & $\begin{array}{l}\text { Stool (18 bulk } \\
\text { stool samples } \\
\text { and } 2 \text { rectal } \\
\text { swabs) }\end{array}$ & Crystal VC & Culture & 20 \\
\hline $\begin{array}{l}\text { George et al., } \\
2014 \text { [22] }\end{array}$ & Bangladesh & 2013 & $\begin{array}{l}\text { Cross- } \\
\text { sectional }\end{array}$ & Median $=32$ & Lab technician & Not reported & $\begin{array}{l}\text { Hospital samples: Patients } \\
\text { presenting to the icddr, b hospital } \\
\text { with moderate to severe } \\
\text { dehydration and acute watery } \\
\text { diarrhea. }\end{array}$ & Stool & Crystal VC & Culture & 125 \\
\hline $\begin{array}{l}\text { Boncy et al., } \\
2013 \text { [23] }\end{array}$ & Haiti & 2011 & $\begin{array}{l}\text { Cross- } \\
\text { sectional }\end{array}$ & Not reported & Lab technician & Not reported & $\begin{array}{l}\text { Hospital samples: Patients with } \\
\text { acute rice watery diarrhea. }\end{array}$ & Stool & Crystal VC & Culture & 644 \\
\hline $\begin{array}{l}\text { Ley et al., } \\
2012[24]\end{array}$ & Tanzania & 2009 & $\begin{array}{l}\text { Cross- } \\
\text { sectional }\end{array}$ & Not reported & $\begin{array}{l}\mathrm{Lab} \\
\text { technician/Field } \\
\text { workers }\end{array}$ & No & $\begin{array}{l}\text { Hospital samples: Patients } \\
\text { presenting to treatment centers } \\
\text { with watery diarrhea. }\end{array}$ & Stool & Crystal VC & Culture & 622 \\
\hline $\begin{array}{l}\text { Page et al., } \\
2012[25]\end{array}$ & DR Congo & 2008 & $\begin{array}{l}\text { Cross- } \\
\text { sectional }\end{array}$ & $>5$ & $\begin{array}{l}\text { Lab } \\
\text { technician/Field } \\
\text { worker }\end{array}$ & No & $\begin{array}{c}\text { Hospital samples: Patients } \\
\text { presenting to cholera treatment } \\
\text { centers with acute watery diarrhea. }\end{array}$ & Stool & Crystal VC & $\begin{array}{c}\text { Culture } \\
\text { and/or PCR }\end{array}$ & 256 \\
\hline $\begin{array}{l}\text { Mukherjee et al., } \\
2010 \text { [26] }\end{array}$ & India & 2008 & $\begin{array}{l}\text { Cross- } \\
\text { sectional }\end{array}$ & All age groups & Lab technician & Not reported & $\begin{array}{l}\text { Hospital samples: Hospitalized } \\
\text { patients with diarrhea. }\end{array}$ & Stool & Crystal VC & Culture & 212 \\
\hline $\begin{array}{l}\text { Harris et al., } \\
2009 \text { [27] }\end{array}$ & Guinea-Bissau & 2008 & $\begin{array}{l}\text { Cross- } \\
\text { sectional }\end{array}$ & Median $=27$ & Lab technician & Not reported & $\begin{array}{l}\text { Hospital samples: Patients } \\
\text { presenting to a hospital cholera } \\
\text { ward. }\end{array}$ & Stool & Crystal VC & PCR & 101 \\
\hline \multirow{2}{*}{$\begin{array}{l}\text { Wang et al., } \\
2006[28]\end{array}$} & \multirow{2}{*}{ Mozambique } & \multirow{2}{*}{2004} & \multirow{2}{*}{$\begin{array}{l}\text { Cross- } \\
\text { sectional }\end{array}$} & \multirow{2}{*}{$\begin{array}{c}\text { Mean }=20 \\
\text { (cholera) and } 24 \\
\text { (non-cholera) }\end{array}$} & \multirow{2}{*}{ Lab technician } & \multirow{2}{*}{ No } & \multirow{2}{*}{$\begin{array}{l}\text { Hospital samples: Patients with } \\
\text { acute non-blood watery diarrhea. }\end{array}$} & Bulk stool & $\begin{array}{l}\text { Institut Pasteur } \\
\text { cholera dipstick }\end{array}$ & Culture & 172 \\
\hline & & & & & & & & Rectal swabs & $\begin{array}{l}\text { Institut Pasteur } \\
\text { cholera dipstick }\end{array}$ & Culture & 219 \\
\hline $\begin{array}{l}\text { Bhuiyan et al., } \\
2003[29]\end{array}$ & Bangladesh & 2002 & $\begin{array}{l}\text { Cross- } \\
\text { sectional }\end{array}$ & 24 & Lab technician & Not reported & $\begin{array}{l}\text { Hospital samples: Patients } \\
\text { hospitalized at the icddr, b for } \\
\text { diarrhea. }\end{array}$ & Rectal swabs & $\begin{array}{l}\text { Institut Pasteur } \\
\text { cholera dipstick }\end{array}$ & Culture & 134 \\
\hline
\end{tabular}

Definition of abbreviations: RDT = rapid diagnostic test; $\mathrm{PCR}=$ polymerase chain reaction, icddr, $\mathrm{b}=$ International Centre for Diarrhoeal Disease Research, Bangladesh 
Table A2. Raw data extracted from studies included in the meta-analysis.

\begin{tabular}{|c|c|c|c|c|c|c|c|}
\hline \multirow[t]{2}{*}{ Study } & \multirow[t]{2}{*}{ Index Test } & \multirow[t]{2}{*}{$\begin{array}{l}\text { Sample } \\
\text { Tested }\end{array}$} & \multirow{2}{*}{$\begin{array}{c}\text { Direct Specimen } \\
\text { or after } \\
\text { Enrichment }\end{array}$} & \multicolumn{4}{|c|}{ Results, $n$} \\
\hline & & & & $\begin{array}{c}\text { True } \\
\text { Positive }\end{array}$ & $\begin{array}{c}\text { False } \\
\text { Positive }\end{array}$ & $\begin{array}{c}\text { False } \\
\text { Negative }\end{array}$ & $\begin{array}{c}\text { True } \\
\text { Negative }\end{array}$ \\
\hline Debes et al., 2021 [13] & $\begin{array}{l}\text { Crystal } \\
\text { VC-O1 }\end{array}$ & Stool & Direct & 79 & 0 & 2 & 149 \\
\hline \multirow{3}{*}{$\begin{array}{c}\text { Chowdhury et al., } \\
2021[14]\end{array}$} & SD Bioline & Stool & Direct * & 115 & 11 & 105 & 275 \\
\hline & SMART-II & Stool & Direct * & 128 & 22 & 92 & 264 \\
\hline & Crystal VC & Stool & Direct * & 122 & 9 & 98 & 277 \\
\hline \multirow{6}{*}{$\begin{array}{c}\text { Chowdhury et al., } \\
2021 \text { [14] }\end{array}$} & \multirow{2}{*}{ SD Bioline } & \multirow{2}{*}{ Stool } & Direct & 105 & 21 & 24 & 356 \\
\hline & & & Direct ** & 111 & 3 & 45 & 347 \\
\hline & \multirow{2}{*}{ SMART-II } & \multirow{2}{*}{ Stool } & Direct & 111 & 39 & 18 & 338 \\
\hline & & & Direct $* *$ & 123 & 19 & 33 & 331 \\
\hline & \multirow{2}{*}{ Crystal VC } & \multirow{2}{*}{ Stool } & Direct & 107 & 24 & 22 & 353 \\
\hline & & & Direct ** & 122 & 6 & 34 & 344 \\
\hline \multirow{2}{*}{ Chibwe et al., 2020 [16] } & \multirow{2}{*}{ Cholkit } & \multirow{2}{*}{ Stool } & Direct & 53 & 1 & 4 & 22 \\
\hline & & & Enrichment & 56 & 0 & 1 & 23 \\
\hline \multirow{8}{*}{ Islam et al., 2019 [17] } & \multirow{4}{*}{ Crystal VC } & \multirow{4}{*}{ Stool } & Direct & 18 & 47 & 7 & 309 \\
\hline & & & Direct & 117 & 1308 & 45 & 4395 \\
\hline & & & Enrichment & 17 & 9 & 8 & 347 \\
\hline & & & Enrichment & 28 & 53 & 13 & 520 \\
\hline & \multirow{4}{*}{ Cholkit } & \multirow{4}{*}{ Stool } & Direct & 19 & 35 & 6 & 321 \\
\hline & & & Direct & 27 & 166 & 7 & 1155 \\
\hline & & & Enrichment & 16 & 21 & 9 & 335 \\
\hline & & & Enrichment & 20 & 22 & 10 & 372 \\
\hline \multirow{2}{*}{ Mwaba et al., 2018 [19] } & \multirow{2}{*}{ SD Bioline } & \multirow{2}{*}{ Stool } & Direct & 60 & 5 & 6 & 99 \\
\hline & & & Enrichment & 63 & 0 & 3 & 104 \\
\hline Denue, 2018 [21] & Crystal VC & Stool & Direct & 97 & 22 & 5 & 32 \\
\hline \multirow{2}{*}{ Sayeed et al., 2018 [18] } & Cholkit & Stool & Direct & 19 & 11 & 2 & 44 \\
\hline & Crystal VC & Stool & Direct & 19 & 11 & 2 & 44 \\
\hline \multirow{3}{*}{ Matias et al., 2017 [31] } & Crystal VC & Stool & Direct & 282 & 65 & 3 & 135 \\
\hline & SD Bioline & Stool & Direct & 197 & 15 & 46 & 193 \\
\hline & Artron & Stool & Direct & 73 & 17 & 1 & 35 \\
\hline Bwire et al., 2017 [30] & Crystal VC & $\begin{array}{l}\text { Stool/Rectal } \\
\text { swabs }\end{array}$ & Enrichment & 91 & 1 & 1 & 9 \\
\hline \multirow{2}{*}{$\begin{array}{l}\text { Ontweka et al., } \\
2016 \text { [32] }\end{array}$} & Cructal ve & Stool & Direct & 34 & 13 & 2 & 44 \\
\hline & Crystal ve & Sivor & Enrichment & 31 & 0 & 5 & 64 \\
\hline Debes et al., 2016 [20] & Crystal VC & Stool & Enrichment & 25 & 3 & 7 & 638 \\
\hline Vijaya et al., 2015 [15] & Crystal VC & Stool & Direct $* *$ & 10 & 5 & 0 & 5 \\
\hline 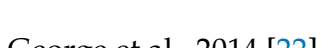 & 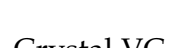 & Stool & Direct & 42 & 5 & 22 & 56 \\
\hline George el al., 2014 [2Z] & Crystal ve & St001 & Enrichment & 48 & 1 & 16 & 60 \\
\hline
\end{tabular}


Table A2. Cont.

\begin{tabular}{|c|c|c|c|c|c|c|c|}
\hline \multirow[t]{2}{*}{ Study } & \multirow[t]{2}{*}{ Index Test } & \multirow{2}{*}{$\begin{array}{l}\text { Sample } \\
\text { Tested }\end{array}$} & \multirow{2}{*}{$\begin{array}{c}\text { Direct Specimen } \\
\text { or after } \\
\text { Enrichment }\end{array}$} & \multicolumn{4}{|c|}{ Results, $n$} \\
\hline & & & & $\begin{array}{c}\text { True } \\
\text { Positive }\end{array}$ & $\begin{array}{c}\text { False } \\
\text { Positive }\end{array}$ & $\begin{array}{c}\text { False } \\
\text { Negative }\end{array}$ & $\begin{array}{c}\text { True } \\
\text { Negative }\end{array}$ \\
\hline Boncy et al., 2013 [23] & Crystal VC & Stool & Direct & 381 & 48 & 19 & 196 \\
\hline Ley et al., 2012 [24] & Crystal VC & Stool & Direct & 182 & 220 & 21 & 199 \\
\hline \multirow{4}{*}{ Page et al., 2012 [25] } & \multirow{4}{*}{ Crystal VC } & \multirow{4}{*}{ Stool } & Direct & 142 & 30 & 12 & 72 \\
\hline & & & Direct & 122 & 31 & 32 & 70 \\
\hline & & & Direct & 164 & 8 & 22 & 62 \\
\hline & & & Direct & 171 & 12 & 15 & 57 \\
\hline $\begin{array}{l}\text { Mukherjee et al., } \\
2010 \text { [26] }\end{array}$ & Crystal VC & Stool & Direct & 66 & 38 & 6 & 102 \\
\hline Harris et al., 2009 [27] & Crystal VC & Stool & Direct & 65 & 8 & 2 & 24 \\
\hline \multirow{4}{*}{ Wang et al., 2006 [28] } & \multirow{4}{*}{$\begin{array}{l}\text { Institut } \\
\text { Pasteur } \\
\text { cholera } \\
\text { dipstick }\end{array}$} & \multirow{4}{*}{$\begin{array}{l}\text { Stool/Rectal } \\
\text { swabs }\end{array}$} & Direct & 57 & 10 & 2 & 31 \\
\hline & & & Direct & 10 & 13 & 3 & 46 \\
\hline & & & Enrichment & 45 & 3 & 0 & 40 \\
\hline & & & Enrichment & 19 & 1 & 2 & 109 \\
\hline $\begin{array}{l}\text { Bhuiyan et al., } \\
2003 \text { [29] }\end{array}$ & $\begin{array}{l}\text { Institut } \\
\text { Pasteur } \\
\text { cholera } \\
\text { dipstick }\end{array}$ & Rectal swabs & Enrichment & 65 & 5 & 3 & 61 \\
\hline
\end{tabular}

* Polymerase chain reaction used as gold standard. ${ }^{* *}$ Enriched culture used as gold standard. 
Table A3. QUADAS-2 assessments.

\begin{tabular}{|c|c|c|c|c|c|c|c|}
\hline \multirow[t]{2}{*}{ Study } & \multicolumn{4}{|c|}{ Risk of Bias } & \multicolumn{3}{|c|}{ Applicability Concerns } \\
\hline & $\begin{array}{l}\text { Patient } \\
\text { Selection }\end{array}$ & $\begin{array}{c}\text { Index } \\
\text { Test }\end{array}$ & $\begin{array}{l}\text { Reference } \\
\text { Standard }\end{array}$ & $\begin{array}{l}\text { Flow and } \\
\text { Timing }\end{array}$ & $\begin{array}{l}\text { Patient } \\
\text { Selection }\end{array}$ & $\begin{array}{c}\text { Index } \\
\text { Test }\end{array}$ & $\begin{array}{l}\text { Reference } \\
\text { Standard }\end{array}$ \\
\hline Debes et al., 2021 [13] & & 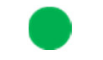 & 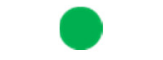 & & & & \\
\hline Chowdhury et al., 2021 [14] & & & & & & $\mathrm{C}$ & \\
\hline Islam et al., 2019 [17] & & & & & & $\mathrm{C}$ & \\
\hline Mwaba et al., 2018 [19] & & & & & & $\mathrm{C}$ & \\
\hline Denue BA, 2018 [21] & & & & & & O & \\
\hline Chibwe et al., 2020 [16] & & & & & & 0 & \\
\hline Sayeed et al., 2018 [18] & & & & & & 0 & \\
\hline Matias et al., 2017 [31] & & & & & & 0 & \\
\hline Bwire et al., 2017 [30] & & & & & & & \\
\hline Ontweka et al., 2016 [32] & & & & & & 0 & \\
\hline Debes et al., 2016 [20] & & & & & & 0 & \\
\hline Vijaya et al., 2015 [15] & & & & & & & \\
\hline George et al., 2014 [22] & & & & & & & \\
\hline Boncy et al., 2013 & & & & & & & \\
\hline Ley et al., 2012 & & & & & & & \\
\hline Page et al., 2012 [25] & & & & & & C & \\
\hline Mukherjee et al., 2010 [26] & & & & & & 0 & \\
\hline Harris et al., 2009 [27] & & & & 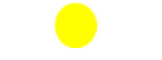 & & 0 & \\
\hline Wang et al., 2006 [28] & & & 0 & & & 0 & \\
\hline Bhuiyan et al., 2003 [29] & & & & & & 0 & \\
\hline
\end{tabular}




\section{References}

1. Clemens, J.D.; Nair, G.B.; Ahmed, T.; Qadri, F.; Holmgren, J. Cholera. The Lancet Cholera. Lancet 2017, 390, 1539-1549. [CrossRef]

2. Richterman, A.; Sainvilien, D.R.; Eberly, L.; Ivers, L.C. Individual and Household Risk Factors for Symptomatic Cholera Infection: A Systematic Review and Meta-analysis. J. Infect. Dis. 2018, 218, S154-S164. [CrossRef] [PubMed]

3. Mutreja, A.; Kim, D.W.; Thomson, N.R.; Connor, T.R.; Lee, J.H.; Kariuki, S.; Croucher, N.J.; Choi, S.Y.; Harris, S.R.; Lebens, M.; et al. Evidence for several waves of global transmission in the seventh cholera pandemic. Nature 2011, 477, 462-465. [CrossRef] [PubMed]

4. Azman, A.S.; Luquero, F.J.; Ciglenecki, I.; Grais, R.F.; Sack, D.A.; Lessler, J. The Impact of a One-Dose versus Two-Dose Oral Cholera Vaccine Regimen in Outbreak Settings: A Modeling Study. PLoS Med. 2015, 12, e1001867. [CrossRef]

5. Keddy, K.H.; Sooka, A.; Parsons, M.B.; Njanpop-Lafourcade, B.M.; Fitchet, K.; Smith, A.M. Diagnosis of Vibrio cholerae O1 infection in Africa. J. Infect. Dis. 2013, 208, S23-S31. [CrossRef]

6. World Health Organization (WHO). Global Task Force on Cholera Control Surveillance Laboratory Working Group. The Use of Cholera Rapid Diagnostic Tests. Available online: https://www.gtfcc.org/wp-content/uploads/2019/10/gtfcc-interim-use-ofcholera-rapid-diagnostic-tests.pdf (accessed on 9 September 2021).

7. Muzembo, B.A.; Kitahara, K.; Debnath, A.; Okamoto, K.; Miyoshi, S. Accuracy of cholera rapid diagnostic tests: A systematic review and meta-analysis. Clin. Microbiol. Infect. 2021, in press. [CrossRef]

8. McInnes, M.D.; Moher, D.; Thombs, B.D.; McGrath, T.A.; Bossuyt, P.M.; Clifford, T.; Cohen, J.F.; Deeks, J.J.; Gatsonis, C.; Hooft L.; et al. Preferred Reporting Items for a Systematic Review and Meta-analysis of Diagnostic Test Accuracy Studies: The PRISMA-DTA Statement. JAMA 2018, 319, 388-396. [CrossRef]

9. Whiting, P.F.; Rutjes, A.W.; Westwood, M.E.; Mallett, S.; Deeks, J.J.; Reitsma, J.B.; Leeflang, M.M.; Sterne, J.A.; Bossuyt, P.M. QUADAS-2: A revised tool for the quality assessment of diagnostic accuracy studies. Ann. Intern. Med. 2011, 155, 529-536. [CrossRef]

10. Schünemann, H.J.; Oxman, A.D.; Brozek, J.; Glasziou, P.; Jaeschke, R.; Vist, G.E.; Williams, J.W., Jr.; Kunz, R.; Craig, J.; Montori, V.M.; et al. Grading quality of evidence and strength of recommendations for diagnostic tests and strategies. BMJ 2008, 336, 1106-1110. [CrossRef]

11. Leeflang, M.M.G.; Deeks, J.J.; Takwoingi, Y.; Macaskill, P. Cochrane diagnostic test accuracy reviews. Syst. Rev. 2013, 2, 82. [CrossRef]

12. Leeflang, M.M.G. Systematic reviews and meta-analyses of diagnostic test accuracy. Clin. Microbiol. Infect. 2014, 20, 105-113. [CrossRef]

13. Debes, A.K.; Murt, K.N.; Waswa, E.; Githinji, G.; Umuro, M.; Mbogori, C.; Roskosky, M.; Ram, M.; Shaffer, A.; Sack, D.A.; et al. Laboratory and Field Evaluation of the Crystal VC-O1 Cholera Rapid Diagnostic Test. Am. J. Trop. Med. Hyg. 2021, 104, $2017-2023$. [CrossRef]

14. Chowdhury, G.; Senapati, T.; Das, B.; Kamath, A.; Pal, D.; Bose, P.; Deb, A.; Paul, S.; Mukhopadhyay, A.K.; Dutta, S.; et al. Laboratory evaluation of the rapid diagnostic tests for the detection of Vibrio cholerae O1 using diarrheal samples. PLoS Negl. Trop. Dis. 2021, 15, e0009521. [CrossRef]

15. Vijaya, D.; TA, D.D. Rapid detection of vibrio cholerae O1 And O139 In stool samples by one-step immunochromatographic dip-stick test. Int. J. Biol. Med. Res. 2015, 6, 4990-4992.

16. Chibwe, I.; Kasambara, W.; Kagoli, M.; Milala, H.; Gondwe, C.; Azman, A.S. Field Evaluation of Cholkit Rapid Diagnostic Test for Vibrio Cholerae O1 During a Cholera Outbreak in Malawi, 2018. Open Forum Infect. Dis. 2020, 7, ofaa493. [CrossRef]

17. Islam, T.; Khan, A.I.; Sayeed, A.; Amin, J.; Islam, K.; Alam, N.; Sultana, N.; Jahan, N.; Rashid, M.; Khan, Z.H.; et al. Field evaluation of a locally produced rapid diagnostic test for early detection of cholera in Bangladesh. PLoS Negl. Trop. Dis. 2019, 13, e0007124. [CrossRef]

18. Sayeed, A.; Islam, K.; Hossain, M.; Akter, N.J.; Alam, N.; Sultana, N.; Khanam, F.; Kelly, M.; Charles, R.C.; Kováč, P.; et al. Development of a new dipstick (Cholkit) for rapid detection of Vibrio cholerae O1 in acute watery diarrheal stools. PLoS Negl. Trop. Dis. 2018, 12, e0006286. [CrossRef]

19. Mwaba, J.; Ferreras, E.; Chizema-Kawesa, E.; Mwimbe, D.; Tafirenyika, F.; Rauzier, J.; Blake, A.; Rakesh, A.; Poncin, M.; Stoitsova, S.; et al. Evaluation of the SD bioline cholera rapid diagnostic test during the 2016 cholera outbreak in Lusaka, Zambia. Trop. Med. Int. Health 2018, 23, 834-840. [CrossRef]

20. Debes, A.K.; Ateudjieu, J.; Guenou, E.; Ebile, W.; Sonkoua, I.T.; Njimbia, A.C.; Steinwald, P.; Ram, M.; Sack, D.A. Clinical and Environmental Surveillance for Vibrio cholerae in Resource Constrained Areas: Application During a 1-Year Surveillance in the Far North Region of Cameroon. Am. J. Trop. Med. Hyg. 2016, 94, 537-543. [CrossRef]

21. Denue, B.A. Evaluation of a rapid dipstick test $\left(\right.$ Crystal $\left.\mathrm{Vc}^{\circledR}\right)$ for the diagnosis of cholera in Maiduguri, Northeastern Nigeria. Arch. Med. Health Sci. 2018, 6, 24-27. [CrossRef]

22. George, C.M.; Rashid, M.-U.; Sack, D.A.; Sack, R.B.; Saif-Ur-Rahman, K.M.; Azman, A.; Monira, S.; Bhuyian, S.I.; Mahmud, M.T.; Mustafiz, M.; et al. Evaluation of enrichment method for the detection of Vibrio cholerae O1 using a rapid dipstick test in Bangladesh. Trop. Med. Int. Health 2014, 19, 301-307. [CrossRef]

23. Boncy, J.; Rossignol, E.; Dahourou, G.; Hast, M.; Buteau, J.; Stanislas, M.; Moffett, D.; Bopp, C.; Balajee, S.A. Performance and utility of a rapid diagnostic test for cholera: Notes from Haiti. Diagn. Microbiol. Infect. Dis. 2013, 76, 521-523. [CrossRef] 
24. Ley, B.; Khatib, A.M.; Thriemer, K.; Von Seidlein, L.; Deen, J.; Mukhopadyay, A.; Chang, N.-Y.; Hashim, R.; Schmied, W.; Busch, C.J.L.; et al. Evaluation of a rapid dipstick (Crystal VC) for the diagnosis of cholera in Zanzibar and a comparison with previous studies. PLoS ONE 2012, 7, e36930. [CrossRef]

25. Page, A.-L.; Alberti, K.P.; Mondonge, V.; Rauzier, J.; Quilici, M.-L.; Guerin, P. Evaluation of a rapid test for the diagnosis of cholera in the absence of a gold standard. PLoS ONE 2012, 7, e37360. [CrossRef]

26. Mukherjee, P.; Ghosh, S.; Ramamurthy, T.; Bhattacharya, M.K.; Nandy, R.K.; Takeda, Y.; Nair, G.B.; Mukhopadhyay, A.K. Evaluation of a rapid immunochromatographic dipstick kit for diagnosis of cholera emphasizes its outbreak utility. Jpn. J. Infect. Dis. 2010, 63, 234-238.

27. Harris, J.R.; Cavallaro, E.C.; De Nóbrega, A.A.; Dos, S.; Barrado, J.C.; Bopp, C.; Parsons, M.B.; Djalo, D.; Fonseca, F.G.D.S.; Ba, U.; et al. Field evaluation of crystal VC Rapid Dipstick test for cholera during a cholera outbreak in Guinea-Bissau. Trop. Med. Int. Health 2009, 14, 1117-1121. [CrossRef]

28. Wang, X.-Y.; Ansaruzzaman, M.; Vaz, R.; Mondlane, C.; Lucas, M.E.S.; Von Seidlein, L.; Deen, J.L.; Ampuero, S.; Puri, M.; Park, T.; et al. Field evaluation of a rapid immunochromatographic dipstick test for the diagnosis of cholera in a high-risk population. BMC Infect. Dis. 2006, 6, 17. [CrossRef]

29. Bhuiyan, N.A.; Qadri, F.; Faruque, A.S.G.; A Malek, M.; Salam, M.A.; Nato, F.; Fournier, J.M.; Chanteau, S.; Sack, D.A.; Nair, G.B. Use of dipsticks for rapid diagnosis of cholera caused by Vibrio cholerae O1 and O139 from rectal swabs. J. Clin. Microbiol. 2003, 41, 3939-3941. [CrossRef]

30. Bwire, G.; Orach, C.G.; Abdallah, D.; Debes, A.K.; Kagirita, A.; Ram, M.; Sack, D.A. Alkaline peptone water enrichment with a dipstick test to quickly detect and monitor cholera outbreaks. BMC Infect. Dis. 2017, 17, 726. [CrossRef]

31. Matias, W.R.; Julceus, E.F.; Abelard, C.; Mayo-Smith, L.M.; Franke, M.; Harris, J.B.; Ivers, L.C. Laboratory evaluation of immunochromatographic rapid diagnostic tests for cholera in Haiti. PLoS ONE 2017, 12, e0186710. [CrossRef]

32. Ontweka, L.N.; Deng, L.O.; Rauzier, J.; Debes, A.K.; Tadesse, F.; Parker, L.A.; Wamala, J.F.; Bior, B.K.; Lasuba, M.; But, A.B.; et al. Cholera Rapid Test with Enrichment Step Has Diagnostic Performance Equivalent to Culture. PLoS ONE 2016, 11, e0168257. [CrossRef] [PubMed]

33. Ngwa, M.C.; Wondimagegnehu, A.; Okudo, I.; Owili, C.; Ugochukwu, U.; Clement, P.; Devaux, I.; Pezzoli, L.; Ihekweazu, C.; Jimme, M.A.; et al. The multi-sectorial emergency response to a cholera outbreak in Internally Displaced Persons camps in Borno State, Nigeria, 2017. BMJ Glob. Health 2020, 5, e002000. [CrossRef] [PubMed]

34. Kohn, M.A.; Carpenter, C.; Newman, T.B. Understanding the direction of bias in studies of diagnostic test accuracy. Acad. Emerg. Med. 2013, 20, 1194-1206. [CrossRef] [PubMed]

35. Nelson, E.J.; Grembi, J.A.; Chao, D.L.; Andrews, J.R.; Alexandrova, L.; Rodriguez, P.H.; Ramachandran, V.V.; Sayeed, M.A.; Wamala, J.F.; Debes, A.K.; et al. Gold Standard Cholera Diagnostics Are Tarnished by Lytic Bacteriophage and Antibiotics. J. Clin. Microbiol. 2020, 58, e00412-20. [CrossRef]

36. Alam, M.; Hasan, N.A.; Sultana, M.; Nair, G.B.; Sadique, A.; Faruque, A.S.G.; Endtz, H.P.; Sack, R.B.; Huq, A.; Colwell, R.R.; et al. Diagnostic limitations to accurate diagnosis of cholera. J. Clin. Microbiol. 2010, 48, 3918-3922. [CrossRef]

37. Bouzid, D.; Zanella, M.C.; Kerneis, S.; Visseaux, B.; May, L.; Schrenzel, J.; Cattoir, V. Rapid diagnostic tests for infectious diseases in the emergency department. Clin. Microbiol. Infect. 2021, 27, 182-191. [CrossRef] 